\title{
Koulun ja yleisen kirjaston yhteistyö opetussuunnitelmissa - tapaustutkimus Lukuinto-ohjelman osallistujien paikallisista opetussuunnitelmista
}

\author{
Siinamari Tikkinen \\ Oulun yliopisto \\ siinamari.tikkinen@gmail.com \\ https://orcid.org/0000-0002-8398-5890
}

Suomalaisoppilaiden lukutaidot ovat olleet erinomaisella tasolla ensimmäisestä PISA-vertailusta lähtien (OECD, 2001, 2010, 2016). Vuoden 2010 PISAtutkimuksessa oppilaiden lukumotivaatio oli kuitenkin alhainen, vaikka lukutaidot olivat edelleen huipun tuntumassa (OECD, 2010). Tästä tilanteesta huolestuneena Suomen opetus- ja kulttuuriministeriö rahoitti vuonna 2012-2015 Lukuinto-ohjelman, jossa pyrittiin lisäämään oppilaiden lukumotivaatiota koulujen ja yleisten kirjastojen yhteistyössä.

Perusopetuksen opetussuunnitelman perusteet (Opetushallitus, 2014) uudistettiin samaan aikaan kuin Lukuinto-ohjelma oli käynnissä. Näin ollen Lukuinto-koulu- ja -kirjastoparien tehtävänä oli suunnitella sellaisia lukumotivaatiota edistäviä menetelmiä, jotka tukevat uuden opetussuunnitelman vaatimuksia. Tässä tutkimuksessa selvitettiin, miten seitsemän Lukuinto-paria sovelsi lukutaitoihin ja koulun ja kirjaston väliseen yhteistyöhön liittyviä periaatteita perusopetuksen opetussuunnitelman perusteista paikallisiin opetussuunnitelmiin. Lisäksi tutkimuksessa haastateltiin kirjastoammattilaisia ja opettajia siitä, millaista yhteistyötä he tekevät käytännössä paikallisiin opetussuunnitelmiin nojaten. Haastattelussa verrattiin 
suositeltua opetussuunnitelmaa opetettuun opetussuunnitelmaan (ks. Cuban, 1992).

Tutkimustulosten pohjalta useat Lukuintoon osallistuneet koulut ja kirjastot olivat sisällyttäneet yhteistyötä koskevia sisältöjä vuonna 2016 voimaan astuviin paikallisiin opetussuunnitelmiin tarkemmin kuin aiempiin opetussuunnitelmiin. Osallistujista kaikki paitsi yksi koulu-kirjastopari työskentelivät niin sanotun Kirjastoreitin mukaisesti. Suositeltu opetussuunnitelma nimettiin Kirjastoreitiksi yhden osallistujan opetussuunnitelman perusteella. Kirjastoreitin idea oli kuvata koulujen ja kirjastojen yhteistyötä eri luokka-asteille suunniteltujen konkreettisten aktiviteettien ja kaikille oppilaille tarkoitettujen kirjastopalveluiden avulla. Opetettu opetussuunnitelma vastasi suositeltua opetussuunnitelmaa, joka sisälsi aktiviteetteja, kuten lukudiplomeita, kirjavinkkausta ja tiedonhaun opastusta. Kirjastot suunnittelivat ja toteuttivat näitä aktiviteetteja suuressa määrin itsenäisesti. Muista poikkeavan koulu-kirjastoparin yhteistyö sisälsi muun muassa lukudiplomeita ja kirjalähetyksiä, mutta heidän yhteistyönsä oli epäsäännöllisempää kuin niiden, joilla oli käytössä Kirjastoreitti.

Lukuinto-parit olivat luoneet Kirjastoreitit jo ennen osallistumista ohjelmaan ja niiden sisällöt pysyivät suunnilleen samana ohjelman päättymisen jälkeen. Vaikka osallistujat olivat tehostaneet yhteistyötä Lukuinto-ohjelman aikana, he eivät olleet yleensä kirjanneet ohjelman aikana toteutettuja menetelmiä Kirjastoreitteihin. Lukuinto-ohjelma päättyi samaan aikaan kuin paikallisten opetussuunnitelmien laadinta alkoi ja näin ollen osallistujat eivät saaneet tukea kirjoitusprosessiin pyynnöistä huolimatta. Tämä voi olla yksi syy siihen, miksi Kirjastoreitit eivät sisältäneet Lukuinto-menetelmiä. Opetussuunnitelmien laatiminen on vaativa prosessi, mikä on huomattu myös aiemmissa tutkimuksissa (esim. Huizinga, Handelzalts, Nieveen, \& Voogt, 2014; Krokfors, 2017). Opetussuunnitelmien laadintaprosessiin tarvitaan paljon ohjausta ja tukea erityisesti, koska valtakunnallinen opetussuunnitelma (2014) antaa vain löyhät raamit koulun ja kirjaston yhteistyön tavoitteista ja sisällöistä.

\section{Lähteet}

Cuban, L. (1992). Curriculum stability and change. Teoksessa P. W. Jackson (toim.), Handbook of research on curriculum : a project of the American Educational Research Association (ss. 216247). New York: Macmillan.

Huizinga, T., Handelzalts, A., Nieveen, N., \& Voogt, J. M. (2014). Teacher involvement in curriculum design: need for support to enhance teachers' design expertise. Journal of Curriculum Studies, 46(1), 33-57. https://doi.org/10.1080/00220272.2013.834077

Krokfors, L. (2017). Opetussuunnitelman pedagogiset mahdollisuudet - opettajat uuden edessä. Teoksessa T. Autio, L. Hakala, \& T. Kujala (toim.), Opetussuunnitelmatutkimus : keskustelu- 
navauksia suomalaiseen kouluun ja opettajankoulutukseen (ss. 247-266). Tampere: Tampere University Press. http://urn.fi/URN: ISBN: 978-952-03-0635-9

OECD. (2001). Knowledge and skills for life: first results from PISA 20oo. Paris: OECD. https:// doi.org/10.1787/9789264195905-en

OECD. (2010). PISA 2009 results: What students know and can do - student performance in reading, mathematics and science (Volume I). Paris: OECD. https://doi .org/10.1787/9789264091450en

OECD. (2016). PISA 2015 results (Volume I): excellence and equity in education. Paris: OECD. https://doi.org/10.1787/9789264266490-en

Opetushallitus. (2014). Perusopetuksen opetussuunitelman perusteet. Helsinki: Opetushallitus. https://www.oph.fi/saadokset_ja_ohjeet/opetussuunnitelmien_ja_tutkintojen_ perusteet/perusopetus 